\title{
Reconstruction of Upper Cretaceous paleoflora based on resin-derived biomarkers. Example from the North Sudetic Basin, Poland
}

\author{
M. GORYL ${ }^{1 *}$, L. MARYNOWSKI ${ }^{2}$, M. BUCHA ${ }^{2}$, B.R.T. \\ SIMONEIT $^{3}$ \\ ${ }^{1}$ Institute of Geological Sciences, Polish Academy of \\ Sciences, Research Centre in Krakow, Poland \\ (*correspondence: magdalena.goryl@gmail.com) \\ ${ }^{2}$ Institute of Earth Sciences, Faculty of Natural Sciences, \\ University of Silecia, Poland \\ (leszek.marynowski@us.edu.pl) \\ ${ }^{3}$ Department of Chemistry, Oregon State University, \\ Corvallis, OR 97331, USA
}

The Upper Cretaceous (Coniacian-Santonian) succession of paralic deposits (sandstones with siltstones and lignite intercalations) is exposed in Rakowice Małe, an inoperative quarry in SW Poland. A wide variety of outcropped lithofacies indicates various types of sedimentation: coastal, lacustrine, paludal and lagoonal [1]. However, due to the poor preservation of wood fragments within these rocks, a very good method to reconstruct palaeoflora is chemotaxonomy - the detailed biomarkers characteristic.

Due low maturity of organic matter (Ro values did not exceed $0.45 \%$ ), certain organic compounds were preserved for tens of millions of years with an unchanged biological structure. Examples of such biomarkers are saccharides and sugar acids, indicating wood-decaying fungi origin [2]. Other group comprises diterpenes: chamaecydins, callitrisic acid, and ferruginol, commonly present in Cupressaceae resins. Simoneit et al. [3] shows that Taxodium distichum resin contains significant amounts of chamaecydins. The ecology of this plant is in line with depositional conditions described by Leszczyński [1] in Rakowice Małe.

Thus, we presume that lands surrounding North Sudetic Basin during Upper Cretaceous were inhabited mostly by trees of Cupressaceae family.

Authors acknowledge financial support from the Polish National Science Centre (grant 2018/31/N/ST10/01646).

[1] Leszczyński (2010) Annales Societatis Geologorum Poloniae 80, 1-24. [2] Marynowski et al. (2019) Int. J Coal Geol. 209, 51-61. [3] Simoneit et al. (2019) Molecules 24(17), 3036. 